\title{
Current approaches to the diagnosis and treatment of resistant hypertension
}

\section{Rezistan hipertansiyonun teşhis ve tedavisinde güncel yaklaşımlar}

\author{
Nurşen KELEŞ, Feyza AKSU, Yusuf YILMAZ, Kenan DEMiRCioĞLU, Mustafa ÇALIŞKAN
}

\begin{abstract}
Resistant hypertension (RHT) is a clinical state in which despite concomitant intake of at least three antihypertensive drugs, one of these preferably being a diuretic at full doses, blood pressure control can not be achieved. Priorly, it should be confirmed that the patients with resistant hypertension have true RHT which can be performed by ruling out factors associated with pseudo-resistance which include inaccurate measurement of blood presure $(B P)$, inadequate treatment plan, non-adherence to prescribed therapy, or the white-coat effect. The complexity of the treatment regimen, socioeconomic status, lifestyle and psychological influences mainly effect compliance to treatment. Treatment methods being researched for the management of RHT include invasive, irreversible such as renal denervation and procedures applied using implantable devices as carotid baroreceptor stimulation. Because of inadequate number of data favouring renal denervation, it is unclear whether renal denervation may benefit a subset of patients with resistant hypertension. For this reason; the best choice for treatment of RHT seems to be full adherence to medication and life style change of patients with RHT.
\end{abstract}

Keywords: Resistant hypertension, diagnosis, treatment öz

Rezistan hipertansiyon (RHT), bir tanesi maksimum dozda diüretik olmak üzere en az üçlü anti-hipertansif tedaviye rağmen kan basıncı kontrolünün sağlanamadığı klinik durum olarak adlandırılır. Öncelikle kan basıncının yanlış ölçümü, yetersiz tedavi planı, tedaviye uymsuzluk veya beyaz önlük etkisi gibi psödo resistan durumların dışlanması, gerçek resistan hipertansiyon tanısı koyabilmek için önemlidir. Tedavi rejiminin karmaşıklığı,sosyoekonomik statü, yaşam şekli psikolojik etkiler tedavi ye uyumu etkileyen temel etmenlerdir. RHT için araştırılmakta olan tedaviler arasında renal denervayson gibi invazif geri dönüşümsüz prosedürler ve karotis baroreseptör stimulasyonu gibi implante edilebilir aletler ile yapılan tedaviler RHT için araştırılmakta olan tedaviler arasında yer almaktadır. Renal denarvasyonun RHT tedavisindeki yeri ve faydası hakkında yeterli olumlu veri bulunmamdığından bu hastalar için en iyi tedavi şeklinin tedaviye tam uyumun sağlaması ve yaşam şekli değişikliği olduğu söylenebilir.

Anahtar kelimeler: Rezistan hipertansiyon, teşhis, tedavi

\section{Giriş}

Hipertansiyon gelişmiş ve gelişmekte olan ülkelerde, üç erişkinden birinde bulunması yönünden hekimler ve diğer sağlık personelinin en sık karşılaştığı kronik hastalık olarak önem göstermektedir.

Hipertansiyonu olan hastalar, lipid bozuklukları, glukoz tolerans bozukluğu veya diyabet, ailede erken kardiyovasküler olay öyküsü, obesite ve sigara içiciliği gibi diğer birçok risk faktörüne de sahiptirler.
Hipertansiyon tanı ve tedavisine yönelik çok sayıda klavuz yayımlanmış olmasına rağmen, toplumların önemli bir kısmında hipertansiyon tedavisinde sınırlı bir başarı elde edilmiştir. Bu bağlamda tedavi altındaki hastaların yarısından daha az bir kısmında beklenen kan basıncı kontrolü elde edilebilmiştir ${ }^{1}$.

\section{RESISTAN HIPERTANSIYON TANIMI:}

Hipertansiyon tanısında birçok hastada sistolik kan basıncı değerlerine daha fazla önem atfedilmektedir. Güncel kılavuzlarda hipertansiyon, yineleyen ölçüm- 
lerde sistolik kan basıncının $\geq 140 \mathrm{mmHg}$ veya diyastolik kan basıncının $\geq 90 \mathrm{mmHg}$ veya ikisinin birden olması olarak tanımlanmıştır.

2003 yılında yayımlanan Birleşik Ulusal Kurul Kılavuzu (Joint National Commitee; JNC VII) hipertansiyonda diğer durumlardan bağımsız olarak tedavi hedefini $<140 / 90$ olarak belirtmiştir. Rezistan Hipertansiyon (RHT); bir tanesinin tercihen tam dozda diüretik olduğu en az 3'lü antihipertansif ilaç tedavisine rağmen, kan basıncı kontorolünün sağlanamaması durumu olarak tanımlanır². Amerikan Kalp Birliği (American Herat Association; $\mathrm{AHA}$ ) kan basıncı kontrolünün sağlanması için dört veya daha fazla ilaç gerekliliğini $\mathrm{RHT}$ olarak tanımlamaktadır ${ }^{3}$.

Öncelikle olarak, özelleşmiş tedavilerden yarar görebilecek yüksek riskli hastaları belirlemek amacıyla tanımlanan RHT, sekonder nedenlerin araştırılması ve tedavisini de içeren bir tanım hâline gelmiştir. JNC 7 rezistan hipertansiyonu bir tanesi diüretik olmak üzere maksimal dozda üç farklı gruptan anti-hipertansif tedaviye rağmen, kan basıncının 140/90 mmHg'nin altına düşürülememesi durumu ${ }^{4}, 2008$ AHA kılavuzu ise üçlü anti-hipertansif tedaviye rağmen, kontrol alınamayan veya en az 4 anti-hipertansif ilaç ile kontrol altına alınan kan basıncı yüksekliği ${ }^{3}$ olarak tanımlamaktadır. Bu tanımlamalar yalancı rezistan hipertansiyon ile rezistan hipertansiyon arasında ayrım yapmakta yardımcı olamamaktadır. Uygunsuz kan basıncı ölçümü, beyaz önlük etkisi veya tedaviye uyumsuzluk gibi nedenlerle yüksek olarak belirlenen kan basıncı değerleri psödo-rezistan hipertansiyon olarak değerlendirilmelidir ${ }^{5,6}$. Epidemiyolojik çalışmalarda, psödo-rezistan hipertansiyonun ekarte edilemediğini vurgulamak amaçlı 3'lü anti-hipertansif tedavi altında ofis kan basıncı 140/90 mmHg'nin üzerinde olması durumu aşikar rezistan hipertansiyon olarak belirtilmektedir ${ }^{7}$. Gerçek rezistan hipertansiyonu belirlemek için 24 saat tansiyon Holter'de kan basıncı yüksekliği gösterilmeli, tedavi uyumu kontrol edilerek, ofis kan basıncı ölçümleri uygun teknik ile yapılmalıdır. Bundan dolayı gerçek rezistan hipertansiyon üçlü anti-hipertansif ilaç kullandığı doğrulanan bir hastada, uygun ölçüm ile alınan ofis kan basıncının
140/90 mmHg'nin üzerinde olması ve 24 saatlik ambulatuar kan basıncı ortalamasının 130/80 mmHg'nin üzerinde olması olarak tanımlanabilir. Gerçek rezistan hipertansiyon prevalansını hesaplayabilmek için en önemli noktalardan birisi de psödorezistan hipertansif hastaları test populasyonundan dışlayabilmektir.

\section{Rezistan Hipertansiyon Tanısı:}

Klinisyen rezistan hipertansiyon tanısı koymadan önce, beyaz önlük etkisi olmadığından ve ilaçların düzenli kullanıldığından emin olmalıdır. Bazen ev tansiyon ölçümlerinin ve 24 saatlik tansiyon Holter ortalamalarının normal olmasına rağmen, ofis kan basıncı ölçümlerinin yüksek olduğu durumlar klinisyenin yanIışlıkla rezistan hipertansiyon tanısı koymasına neden olabilir. Beyaz önlük etkisi (24 saatlik ambulatuar kan basıncı ölçümlerinin normal sınırlarda olmasına rağmen, ofis kan basıncı ölçümünün 140/90 mmHg veya üzerinde olması) olarak bilinen bu durumun sıklığının en az üç anti hipertansif kullanımına rağmen, ofis kan basıncı değerleri yüksek ölçülen hastalarda \%30'larda olduğu yakın zamanlı bir çalışmada gösterilmiştir ${ }^{8}$.

Birçok çalışmada, beyaz önlük etkisi bulunan hastaların iyi tansiyon kontrolüne sahip olanlarla benzer ve rezistan hipertansiyonu olanlara göre daha düşük kardiyovasküler olay oranına sahip oldukları gösterilmiştir ${ }^{9,10}$.

\section{İlaç Uyumsuzluğuna Bağlı Psödorezistan Hipertansiyon:}

Başlangıçta, geniş çaplı çalışmalarda yoğun antihipertansif tedaviye rağmen, RHT prevelansı \%20-30 olarak belirtilmekteydi. Fakat bu çalışmaların büyük çoğunluğu hastaya reçete edilen ilaçların hasta tarafından uygun şekilde ve dozda kullanıldığını kabul etmekte ve kan basıncı ölçümlerini ofis ölçümlerine dayandırmaktaydı ${ }^{11}$. Gerçek rezistan hipertansiyon tanısını koyabilmek için öncelikle psödo rezistansa neden olan ilaç uyumsuzluğu, beyaz önlük etkisi, yanlış ilaç seçimi ve yanlış kan basıncı ölçümü gibi durumlar ekarte edilmelidir. Bu durumların ekartasyonu yapıldığında rezistan hipertansiyon prevelansının \%15'in altında olduğu ve rezistan hipertansiyon 
olarak değerlendirilen hastaların önemli bir çoğunluğunun psödo rezistan olduğu görülmüştür ${ }^{12-14}$.

Reçete edilen anti hipertansiflere uyumsuzluğa bağIı psödo rezistan hipertansiyon hastalarını dışlamak karşılaşılan majör güçlüklerden biridir ve önceki epidemiyolojik değerlendirmelerde bu ayırımın eksik olduğu görülmektedir ${ }^{14}$. Kan basıncı kontrolü ile anti hipertansif tedaviye uyum arasındaki ilişkiye araştıran bir çalışmada, 359 hastadan 152'sinin $(\% 43,9)$ tedaviye uyum göstermediği ve $40(\% 11,1)$ hastanın resitan hipertansiyon kriterlerine sahip olduğu görülmüştür. Psödo-rezistans yaygın olarak yanlış rezistan hipertansiyon tanısı almaktadır. Bir epidemiyolojik çalışmada kontrolsüz kan basıncı olan 152 olgudan 98 'inin $(\% 62,4)$ reçete edilen anti-hipertansif tedaviyi uygulamadığı, bu nedenle kan basıncı kontrolünün sağlanamadığı ve rezistan hipertansiyon olarak yanlış tanı aldıkları görülmüştür. Bu çalışma, rezistan hipertansiyon olarak tanı almış hastalarda ilaç uyumsuzluğunun az bilinmesine rağmen, önemli bir etken olduğunu göstermektedir. Daugherty ve ark. ${ }^{15}$, daha önce rezistan hipertansiyon ile ilgili yapılan çalışmaların ortak bir rezistan hipertansiyon tanımlamasının olmaması, uzun dönemli kan basıncı takiplerinin eksikliği ve ilaç uyumsuzluğuna bağlı psödo-rezistansın dışlanamaması nedeni ile kısıtlı olduğunu belirtmektedirler. Bu nedenle kan basıncı ölçümü için sistolik ve diyastolik kan basıncının altı adet ölçüm ortalamasının alındığı, araştırma ekibinin 15 gün içerisinde üç kez ev ziyareti yaptığı ve ölçümlerin beyaz önlük etkisini minimize etmek amaçlı hastanın evinde yapıldığı kalibre edilmiş civalı manometrelerin kullanıldığı standart bir protokol oluşturulmuştur ${ }^{16}$. Morisky Medication Adherence System 8 (MMAS-8) ilaç uyumunu ölçmek için kullanılmıştır ${ }^{17}$ ve MMAS 8 skorunun 6 ve üzerinde olması bu çalışmada uyumluluk olarak kabul edilmiştir ${ }^{18}$. Metodolojilerinde kişisel raporlama sistemlerinin kullanılmış olması, ucuz, hızlı ve invazif olmayan bir yöntem olarak dikkat çekmekle birlikte, uyumsuzluk düzeyinin olduğundan daha az hesaplanması bir eksiklik olarak bildirilmiştir. İlaç uyumunu ölçmek için kullanılabilen objektif bir teknik de toksikolojik idrar analizleridir. 1980'lerden bu yana genel toksikolojik idrar analizlerinde sistematik bir gelişme izlenmekte olup, ilk kullanılan yöntem gaz kromatografi-kütle spektrometre (GC-MS) dir ${ }^{19,20}$. Likid kromatografi kütle spektrometre (LC-MS) nin geliştirilmesi ile anti-hipertansiflerin de dahil olduğu çeşitli ilaç gruplarının analizleri yapılabilmektedir ${ }^{21-24}$. Düşük yaşam kalitesine sahip olan bireylerin antihipertansif tedaviye uyum oranları da düşük olma eğilimindendir. Bu nedenle rezistan hipertansiyon tanısı, uyumsuzluğa yol açan nedenlerin araştırılması ve uyumsuzluğun ekartasyonunu içermelidir ${ }^{25}$. Böylece fazla ilaç kullanımına ve invazif girişimlere gerek kalmadan başarılı bir şekilde hipertansiyon tedavisi yapılabilmektedir. Ancak hastaların yalnızca \%5'lik kısmında tek ilaç ile kan basıncı kontrolü sağlanabilmektedir. Bu nedenle çoklu ilaç kullanımından kaçınmak zor olabilmektedir ${ }^{14}$. Özetle, pseodo-rezistan hipertansiyonun yaygın bir nedeni reçete edilen ilaçlara uyumsuzluk gibi görünmekte olup, bu faktörün ortadan kaldırılması ile gereğinden fazla ilaç kullanımına ihtiyaç olmadan ve daha ileri invazif tedavilere gerek kalmadan kan basıncı kontrolü sağlanabilir gibi gözükmektedir.

\section{RESISTAN HIPERTANSIYON TEDAVISI:}

\section{Rezistan Hipertansiyon Hastaları İçin Yaşam Tarzı Değişiklikleri:}

RHT prevelansındaki öngörülen artış 3, sonucu etkileyebilecek efektif tedavilere gereksinimi artırmıştır. RHT kontrolünde, renal denarvasyon, karotis baroreseptör stimülasyonu gibi yeni invazif, irreversible prosedürler ve implante edilebilir aygıtlar geliştirilmektedir. Fakat öncelikle invazif olmayan, hastanın rahatını bozmayan ve komplikasyona yol açmayacak tedavilerin geliştirilmesi önem göstermektedir. Hipertansiyon kılavuzları kilo verme, fiziksel aktiviteyi artırma, anti-hipertansif diyet (Dietary Approaches to Stop Hypertension-DASH), tuz alımının kısıtlanması, sigaranın bırakılması gibi yaşam tarzı değişikliklerini anti hipertansif tedaviye tamamlayıcı olarak önermektedir ${ }^{2,4}$. Yaşam tarzı değişiklikleri ile hipertansif hastaların mortalite-morbiditesi arasındaki ilişkiyi araştıran çalışmaların sonuçları bu önerilerin temelini oluşturmaktadır ${ }^{26,27}$. 
Rezistan hipertansiyonu olan bütün bireyler yaşam tarzı değişikliği açısından bilinçlendirilmelidir. Tuz alımı rezistan hipertansiyona katkıda bulunan temel etmenlerdendir. Geniş çaplı klinik çalışmaların meta analizlerinde, diyetle alınan sodyumdaki $1.7 \mathrm{~g} /$ günlük bir kısıtlamanın, hafif komplikasyonsuz hipertansiflerde kan basıncı değerlerinde $5 / 3$ mmHg'lik bir azalmaya yol açtığı bildirilmiştir ${ }^{28}$. Sodyum alımının kısıtlanması rezistan hipertansiyon kontrolünde daha etkili bulunmuş olup, bir tanesi diüretik olmak üzere üçlü anti hipertansif tedaviye rağmen, kan basıncı kontrolü sağlanamayan hastalarda günlük tuz alımında ortalama 1.1 g'lık kısıtlama ile 24 saatlik ambulatuvar kan basıncı ölçümlerinde ortalama $23 / 9 \mathrm{mmHg}$ 'lık bir düşüş olduğu gösterilmiştir ${ }^{29}$. Buna rağmen, Amerika Birleşik Devletler'inde günlük ortalama sodyum tüketimi, önerilen değerlerin üzerinde olup (günlük 8,5 $\mathrm{g} / \mathrm{tuz})$, tüketilen sodyumun $\% 75^{\prime} \mathrm{i}$ işlenmiş gıdalar ve restoran yemeklerinden, $\% 25^{\prime} \mathrm{i}$ de yemeklere eklenen tuzlardan alınmaktadır ${ }^{30}$. İyi kan basıncı kontrolü ve sodyum alımının düzenlenmesi için, bireylerin tüketilen gıdaların içeriklerini okumaları konusunda bilinçlendirilmeleri gerekmektedir.

Hastaların \%40'lık grubunda fiziksel inaktivite dikkat çekmekte olup, kılavuzlar hipertansif hastalar için haftanın çoğu gününde olacak şekilde günde en az $30 \mathrm{dk}$. aerobik fiziksel aktivite önermektedir ${ }^{2,3}$. Yakın zamanlı randomize bir çalışmada, 8 ila 12 hafta boyunca haftada 3 kez koşu bandında yürütülen bir gurup rezistan hipertansiyon hastası, sedanter yaşam tarzına sahip grup ile kıyaslandığında, kan basıncında ortalama $6 / 3 \mathrm{mmHg}$ düşüş sağlanmış olup, rezistan hipetansiyon hastalarına aerobik egzersizin önemini göstermek açısından etkili bir çalışma olmuştur ${ }^{31}$.

Anti hipertansif almakta olan hastalarda yaşam tarzı değişikliklerinin önemini gösteren geniş çaplı araştırmalar olmamasına rağmen, bir veya iki ilaç kullanan hastalarda umut verici yayınlar bulunmaktadır. Anti hipertansif kullanmakta olan ve kan basıncı kontrolü sağlanamayan Afrikan Amerikan erkeklerin bulunduğu küçük çaplı bir çalışmada, düzenli egzersizin tek başına diyastolik kan basıncında azalmaya ve sol ventriküler hipertofisinde (SVH) gerilemeye yol açtığı görülmüştür ${ }^{32}$. Ayrıca TONE çalışmasında, tekli anti hipertansif alan yaşlı hastalarda sodyum kısıtlaması ve kilo kaybının, kan basıncı kontrolü sağlamayı kolaylaştırdığı gösterilmiştir ${ }^{33}$.

Anti hipertansif atında olan hastalarda DASH diyetinin etkilerini gösteren kısıtlı veriler mevcuttur. Elli beş hipertansif hastanın alındığı bir çalışmada anjiyotensin reseptör bloker (ARB) tedavisine DASH diyetinin eklenmesi ile normal diyete göre $5 \mathrm{mmHg}$ 'nin üzerinde bir kan basıncı düşüşü sağlandığı bildirilmiş$\operatorname{tir}^{34}$. Avusturalya hipertansiyon çalışması olan ADAPT çalışmasında 1 ve/ya 2 ilaç kullanan hipertansiyon hastalarında modifiye DASH diyeti ile kan basıncında hafif $(4 / 2 \mathrm{mmHg})$ bir düşüş elde edilmiş ve istatiksel olarak anlamlı bulunmuştur. Ayrıca anti hipertansif tedavi bağımlılığında bir azalma gözlenmiştir ${ }^{35}$. Kırk dört kilolu ve tekli anti hipertansif ilaç kullanan hastanın bulunduğu 9 haftalık bir beslenme çalışması olan DEW-IT çalışmasında DASH diyeti ile iki kat fazla kilo azalması ve önemli kan basıncı azalması saptanmıştır.

Birçok küçük çaplı çalışmada diyet ve fiziksel aktivitedeki değişimin rezistan hipertansiyon hastalarında kan basıncı kontrolü sağlamada etkili olabileceği gösterilmiştir. Örneğin, 12 rezistan hipertansiyon hastasının alındığı bir çalışmada, 50 mmol/gün (1150 $\mathrm{mg} /$ gün) sodyum içeren beslenme ile $250 \mathrm{mmol} /$ gün (5750 mg/gün) sodyum içeren beslenme karşılaştırıldığında, 24 saatlik ambulatuvar kan basıncı değerlerinde $23 / 9 \mathrm{mmHg}$ düşüş izlenmiştir ${ }^{29}$. Bu çalışmada, tedavi süresi 7 gün olarak alınmış ve tüm yiyecekler araştırma merkezinde hazırlanmıştır. Fakat daha uzun süreli ve yemeklerin özel olarak hazırlanmadığı çalışmalarda da aynı sonuçların gösterilmesi kuşkusuz heyecan verici olacaktır. Bir diğer küçük çaplı çalışmada Dimeo ve ark. ${ }^{31} 50$ rezistan hipertansiyonu bulunan hastayı, haftada $3 \mathrm{kez}$ treadmil egzersiz yapan grup ve kontrol grubuna randomize ettiler ve egzersiz grubunda ambulatuar kan basıncında $6 / 3 \mathrm{mmHg}$ 'lik düşüş olduğunu gösterdiler. Bu bilgiler ışığında yaşam tarzı değişikliklerinin rezistan hipertansiyon hastalarında kan basıncında etkili olabileceği düşünülebilir ama daha uzun zamanlı ve geniş çaplı randomize kli- 
nik çalışmalara (RKÇs) ihtiyaç vardır.

\section{Medikal Tedavi:}

Rezistan hipertansiyon tedavisine yaklaşım, hipertansiyon patogenezinde yer alan bozulmuş sodyum dağılımı, volüm yüklenmesi, renin- anjiyotensin- aldesterone sistem (RAAS) aktivitesinde ve sempatik aktivitede artış ve endotel bağımlı vazodilatasyonda azalma gibi major faktörleri hedef almalıdır. Ayrıca bu grup hastalarda daha yaygın olarak görülen non dipper ve gece kan basıncı yüksekliği gibi özel paternlerin tedavisi, hedef organ hasarının gelişiminin önlenmesi ve takibi gibi konulara özel ilgi gösterilmelidir.

\section{Volüm:}

Hipertansif ve normotansif bireylerde tuz kısıtlamasının kan basıncında düşüşe neden olduğu bilinmektedir. DASH-Sodyum çalışmasında, sodyum alımının 100 mmol'den 50 mmol'e düşürülmesinin, 150 mmol'den 100 mmol'e düşürülmeye göre kan basıncında 2 kat etkili olduğu gösterilmiştir ${ }^{36}$. Rezistan hipertansiyonu olan hastalarda günlük sodyum alımının kısıtlanmasının kan basıncı kontrolünde güçlü bir faktör olduğu görülmektedir. Küçük çaplı, rezistan hipertansiyon hastalarını içeren randomize kesitsel bir çalışmada düşük miktarda (50 mol/gün) sodyum alımının, yüksek miktarda (250 mol/gün) sodyum alımına göre ortalama ofis sistolik kan basıncında (SKB) 22.7 mmHg'lik düşüşe ayrıca gün içi, gece ve 24 saatlik kan basıncı değerlerinde düşüş eğiliminin başlamasına sebep olmuştur ${ }^{29}$. Bu nedenle rezistan hipertansiyon, tuz duyarlı tansiyon yüksekliğidir. Rezistan hipertansiyonu ve yüksek 24 saatlik idrar aldesteron seviyeleri olan hastaların alındığı bir çalışmada, idrarda protein atılımının, günlük tuz tüketiminin artışı ile progresif olarak arttığı tespit edilmiş, aldesteron fazlalığı ve diyetle alınan sodyum miktarının artışının etkileşerek, idrar proteininde artışa yol açtığı gösterilmiştir ${ }^{37}$. Randomize, çift kör plasebo kontrollü kesitsel bir çalışmada, diyabetik olmayan proteinürik hastalarda tuz kısıtlamanın tek başına anti hipertansif ve anti proteinürik etki gösterdiği; ayrıca RAAS blokajının antiproteinürik etkilerini diüretik kadar artırdığı gösterilmiştir ${ }^{38}$.
Diüretik tedavisi hipertansiyon tedavisinde genelde etkili dozda kullanılmamaktadır ve diüretik tedavisindeki düzenleme rezistan hipertansiyon hastalarının önemli bir kısmında kan basıncı hedefine ulaşmada etkili olabilmektedir ${ }^{39}$. Örneğin, büyük çalışmalarda diüretik tedavisi olarak klortalidon $25 \mathrm{mg} /$ gün önerilmesine rağmen, daha zayıf etkili hidroklorotiyazid 12,5-25 mg/gün dozlarında dünya çapında en çok reçete edilen diüretik olma özelliğini sürdürmektedir ${ }^{40}$. Çok kullanıımalarına rağmen, 24 saatlik ambulatuvar kan basıncı ölçümlerinde (АKBÖ) 12.5-25 mg/gün hidroklorotiyazid (HKTZ) kullanımı, diğer anti hipertansiflere göre kan basıncı kontrolü sağlamada inferiyor olarak bulunmuştur ${ }^{40}$. Klortalidon HKTZ'e göre iki kat daha etkindir ve daha uzun etki süresine sahiptir (hidrolorotiyazid 8-15 saat klortalidon ise 40 saatten fazla) $)^{41}$. Yirmi dört saatlik AKBÖ kullanılarak yapılan çalışmalarda 25 mg/gün klortalidon kullanımı 50 mg/ gün HTKZ kullanımına göre öncelikle gece SKB'yi düşürerek 24 saatlik ortalama SKB'de belirgin düşüşe sebep olmuştur ${ }^{42}$. Tiyazid diüretiklerin en etkili olduğu gurup glomerular filtrasyon oranının (GFO) 40-50 $\mathrm{ml} / \mathrm{min} / 1.73 \mathrm{~m}^{2 \prime}$ nin üzerinde olduğu hasta grubudur. Klortalidon ise GFO $30-40 \mathrm{ml} / \mathrm{min} / 1.73 \mathrm{~m}^{2}$ aralığında ciddi hipoalbüminemi yokluğunda etkili olabilir. İleri kronik böbrek hastalığında (KBH) loop diüretiklerinden biri tercih edilmelidir. Kısa yarı ömürleri ve tek dozda verildiklerinde aralıklı natriürez ve reaktif RAAS aktivitesinde artış riski sebebi ile furosemid ve bumetanid gibi loop diüretikleri günde en az iki doz olarak verilmelidir ${ }^{43}$. Daha uzun etkili olan torsamid günde tek doz veya iki doz olarak kullanılabilir. Loop diüretiklerini nefronun daha uç kısmına etki eden bir tiayzid diüretik veya düşük doz potasyum tutucu bir diüretikle kombine edilmesi de günlük doz kararını verirken göz önünde bulundurulmalıdır ${ }^{44}$.

\section{Yeterli RAAS Blokajı:}

Anjiyotensin dönüştürücü enzim ( $A D E)$ inhibitörü tedavisi ile RAAS'ı hedef almak, hipertansiyon tedavisinde etkin kan basınc kontrolünü sağlamak, KBH'ye ilerlemeyi yavaşlatmak ve kalp yetmezliğinde mortalite ve morbiditeyi azaltmak amaçlı kullanılan temel tedavilerdendir. Ancak, birçok hastada tedaviye rağ- 
men, hastalığın progresyonunda artış izlenmektedir. Klinik çalışmalar ADE inhibitörü veya $A R B$ tedavisi alan hastalarda başlangıçta plazma aldesteron seviyelerinde bir miktar azalma, ilerleyen dönemde ise \%30-40 civarında bir artış olduğunu göstermektedir. Bu durum aldesteron kaçış fenomeni olarak adlandırılmakta olup, hipertansiyonun sol ventrikül hipertrofisi (SVH), bozulmuş egzersiz kapasitesi, GFO daki hızlı azalma ve üriner albümin atılımında artış gibi olumsuz sonuçlarından sorumlu olduğu gösterilmiş$\operatorname{tir}^{45}$. Bu fenomen hipertansiyon kontrolünde ve hedef organ hasarında aldesteronun yeri ile ilgili bilgilerde değişikliğe yol açmıştır. Aldesteronun yalnızca epitel hücrelerde ve sadece ekstrasellüler sıvı dengesi ve sodyum potasyum hemostazından sorumlu olduğu düşüncesi günümüzde kalp, böbrek ve beyin gibi non epitelyal dokularda da mineralokortikoid reseptörlerinin keşfedilmesi ile değişmiştir. Hayvan çalışmaların da dâhil olduğu birçok çalışmada, aldesteronun vasküler hasarlanma, doku fibrozisi ve inflamasyondaki rolü gösterilmiş olup, özellikle tuzdan zengin ortamların mineralokortikoid reseptör (MR) aktivasyonunun zararlı etkilerini güçlendirdiği de ortaya konulmuştur ${ }^{46}$. RAAS sisteminin eksik blokajına yönelik olarak ADE inhibitörü ve ARB lerin birlikte kullanımı ile kan basıncında tekli tedaviye göre ortalama $4 / 3$ $\mathrm{mmHg}$ 'lik bir düşüş ile proteinüride tekli tedavide \%30 olan azalma, ikili tedavi ile \%39'a yükselmiştir ${ }^{47}$. Fakat kan basıncındaki azalma ve proteinürideki gerilemeye rağmen, kardiyovasküler ve renal olaylar üzerinde olumlu sonuçlar gösterilememiştir. Diğer bir strateji olarak ultra yüksek dozda ADE inhibitörü veya ARB kullanılması denenmiş, yapılan küçük çaplı birçok çalışmada, hipertansif KBH bulanan hastalarda konvansiyonel dozların üzerinde ARB kullanımı ile proteinüride azalma gözlenmiş fakat ek kan basıncı düşüşü saptanamamıştır ${ }^{48}$. ADE inhibitörü veya $A R B$ lerin ikili veya tekli kullanımındaki bu yetersizlik, rezistan hipertansiyon tedavisinde RAAS baskılanmasında spirinolakton veya eplerenon gibi mineralokortikoid reseptör blokerlerinin (MRB) kullanılması düşüncesine olan ilgiyi artırmıştır. Hiperaldesteronizm; rezistan hipertansiyon için ender nedenlerden biri olarak düşünülmekteyken, yakın zamanlı çalışmalar, rezistan hipertansiyonlu bireylerin üçte birinde sürekli eks- trasellüler sıvı fazlalığına rağmen, yüksek aldesteron düzeyleri ve aldesteron renin oranında (ARO) artış olduğunu göstermiştir ${ }^{49}$. Bu bilgiler ile birlikte MRB ler rezistan hipertansiyon tedavisinde efektif olarak kullanılmaya başlanılmıştır. İlerleyen dönemde MRB lerin rezistan hipertansiyondaki yeri üzerine güçlü kanıtlar iki büyük çalışma ile elde edilmiştir. Bunlardan ilki 2007 yılında yayınlanan ASCOT-BPLA (Angloscandinavian Cardiac Outcomes Trial-Blood Pressure Lowering Arm) çalışması olup, spironolakton 25 mg/ gün dozunda başlanmak üzere 4 . kuşak tedavi olarak eklenmesi ile ortalama 1,5 yıllık tedavi süresinde; sistolik kan basıncında ortalama $21.9 \mathrm{mmHg}$ (\%95 Cl: 20.8-23.0 $\mathrm{mmHg}$ ), diyastolik kan basıncında ise 9,5 mmHg (\%95 Cl:9,-1,1 mmHg) düşüş elde edilmiştir ${ }^{50}$. Sonrasında ise randomize, çift kör, plasebo kontrollü ASPIRANT (Addition of Sprinolactone in Patients With Rezistant Arterial Hypertension) çalışması ile 8 haftalık $25 \mathrm{mg} /$ gün dozunda spironolakton tedavisi ile ortalama gündüz SKB değerlerinde $5,4 \mathrm{mmHg}$ $(p=0.02)$ ortalama gece SKB değerlerinde $8.6 \mathrm{mmHg}$ $(p=0.01) 24$ saatlik ortalama SKB değerinde 9,8 $\mathrm{mmHg}(p=0,004)$ ve ofis SKB değerlerinde $6,5 \mathrm{mmHg}$ $(p=0,01)$ azalma izlenmiştir ${ }^{51}$. Yakın potasyum takibi ile $\mathrm{KBH}^{\prime}$ nin erken dönemlerinde veya düşük bazal potasyum seviyesi veya eşzamanlı diüretik kullanımı ile birlikte ilerlemiş evre $\mathrm{KBH}$ de, rezistan hipertansiyon tedavisi için MRB'leri etkin bir seçenek olarak uygulanabilir ${ }^{52,53}$.

\section{Kronoterapi:}

Non-dipper fenomeni olarak bilinen gece kan basıncında beklenen düşüşün olmaması ile rezistan hipertansiyon arasında ilişki bulunmaktadır. AASK kohort çalışmasında katııımcıların \%80'lik kısmını non-dipper profiline sahip hastalar oluşturmuş ve gece sistolik kan basıncı ortalaması yüksek olan bu gurupta, sol ventrikül hipertrofisinde, proteinüri ve $\mathrm{KBH}$ gelişmesi gibi hedef organ hasarı sıklığında daha fazla artış olduğu bildirilmiştir ${ }^{54}$. Klinik çalışmaların ışığında hipertansiyonun tüm evreleri için ve özellikle gerçek rezistan hipertansiyonu olan hastalarda non-dipper profilinin olması, kardiyovasküler mortalite ve morbiditede 2 kat artışa yol açmaktadır ${ }^{55,56}$. Rezistan hipertansiyonu 
olan bireylerde yüksek gece kan basıncının patofizyolojisindeki bozukluk olarak gündüz sodyum atılım kapasitesindeki azalma gösterilmektedir ${ }^{57}$. Bu nedenle kronoterapi yani antihipertansif tedavinin gündüz yerine yatarken alınması şeklinde bir strateji ile kan basıncının sirkadiyan ritmini etkilemek ve non-dipper profilini azaltarak, gece kan basıncı kontrolünü sağlamak hedeflenmiştir. İki yüz elli rezistan hipertansiyon hastasının alındığı bir çalışmada hastalar akşam için yeni bir anti hipertansif başlanan ve yine gündüz almak üzere yeni anti hipertansif başlanan olmak üzere iki gruba randomize edilmişlerdir. Akşam için anti hipertansif eklenen grupta AKB ölçümlerinde 9.4/6.0 $\mathrm{mmHg}$ ortalama değer ile anlamalı bir azalma izlenmiş, non dipping prevelansı ise 12 haftalık tedavi sonrasında \%84'ten \%43'e gerilemiştir ${ }^{58}$. Başka bir çalışmada, diüretik dışındaki tüm anti hipertansiflerin akşam alınması ile ilaç dozu değiştirilmeden rezistan hipertansiyon hastalarında kan basıncı kontrolü açısından yararlı sonuçlar elde edilmiştir ${ }^{59}$. Bu olumlu sonuçlar göz önünde bulundurulduğunda rezistan hipertansiyon veya non-dipper hipertansiyon grubunda bir anti hipertansifi akşam dozunda vermek yararlı bir strateji olarak görülmektedir.

\section{Cihaz tedavisi:}

Rezistan hipertansiyonda cihaz tedavisi özellikle hipertansiyonun patogenezinde etkili olan sempatik sinir sistemini hedef almaktadır ${ }^{60}$. Ancak cihaz tedavisi beklenen can alıcı sonuçları vermemiştir. Karotis sinüsteki sinirlere kronik elektriksel uyarı verilerek, barorefleks aracılı sempatik sinir aktivitesinde inhibisyon oluşturmak amaçlı hastalara cerrahi olarak cihaz yerleştirilen randomize, çift kör bir çalışmada, rezistan hipertansiyon hastaların \%54'ünde kan basıncında düşüş izlenmiştir. Ancak cihazları bilinmeyen nedenlerle deaktive olmuş hastaların \%46'sında da kan basıncı düşüşü izlenmiştir $(p=0,97)^{61}$. Kateter yoluyla renal sempatik denervasyon, rezistan hipertansiyon tedavisi için bir diğer bir strateji olup, renal arterlerdeki advensiya tabakasında bulunan renal sinirlerin radyofrekans ablasyonu şeklinde uygulanmaktadır. $\mathrm{Bu}$ işlemin operatif komplikasyonları, giriş yerinde (femoral arterde) hematom/psödoanevrizma, ablas- yon uygulanan renal arter segmentinde diseksiyon, renal arterde rüptür, uç organ hasarına neden olan embolik olaylar ve postoperatif erken dönemde hipotansiyon olarak sayılabilir. İşlemin uzun dönem komplikasyonu ise işleme bağlı hızlanmış aterosklerotik süreçlere bağlı olarak renal arterde gelişen stenotik aterosklerotik lezyonlar olarak tanımlanmıştır. Bu yöntem uygulanarak yapılan ilk çalışmada yüz güldüren sonuçlar alınmasına rağmen ${ }^{62}$, plasebo kontrollü bir çalışma olan SIMPLICITY-HTN çalışmasının sonuçları tek başına medikal tedavi ile denervasyon arasında ofis kan basıncı ve 24 saatlik AKB ölçümleri arasında anlamlı bir fark olmadığını göstermiştir ${ }^{63}$. Rezistan hipertansiyon hastalarının belli bir kısımında denervasyonun etkili olup olmadığı konusunda kesin bir veri bulunmamaktadır. Bu nedenle RHT tedavisinde en önemli nokta ilaç uyumunu artırmak ve yaşam tarzı değişikliğini uygulamak olarak gözükmektedir.

\section{KAYNAKLAR}

1. Weber MA, Schiffrin EL, White WB, et al. Clinical Practice Guidelines for the Management of Hypertension in the Community A Statement by the American Society of Hypertension and the International Society of Hypertension. The Journal of Clinical Hypertension 2014;16:1

http://dx.doi.org/10.1111/jch.12237

2. Mancia G, Fagard R, Narkiewicz K,et al. ESH/ESC Guidelines for the management of arterial hypertension: the Task Force for the management of arterial hypertension of the European Society of Hypertension (ESH) and of the European Society of Cardiology (ESC). J Hypertens 2013;31:1281-1357. http://dx.doi.org/10.1097/01.hjh.0000431740.32696.cc

3. Calhoun DA, Jones D, Textor S, et al. Resistant hypertension: diagnosis, evaluation, and treatment. A scientific statement from the American Heart Association Professional Education Committee of the Council for High Blood Pressure Research. Hypertension 2008;51:1403-1419.

http://dx.doi.org/10.1161/HYPERTENSIONAHA.108.189141

4. Chobanian AV, Bakris GL, Black HR, et al. National Heart, Lung, and Blood Institute Joint National Committee on Prevention, Detection, Evaluation, and Treatment of High Blood Pressure; National High Blood Pressure Education Program Coordinating Committee. The Seventh Report of the Joint National Committee on Prevention, Detection, Evaluation, and Treatment of High Blood Pressure: the JNC 7 report. JAMA 2003;289:2560-2572.

http://dx.doi.org/10.1001/jama.289.19.2560

5. Sarafidis PA. Epidemiology of resistant hypertension. J Clin Hypertens (Greenwich) 2011;13:523-528. http://dx.doi.org/10.1111/j.1751-7176.2011.00445.x

6. Sarafidis PA, Georgianos P, Bakris GL. Resistant hypertensionits identification and epidemiology. Nat Rev Nephrol 2013;9:51-58.

http://dx.doi.org/10.1038/nrneph.2012.260 
7. Calhoun DA. Apparent and true resistant hypertension: why not the same? J Am Soc Hypertens 2013;7:509-511. http://dx.doi.org/10.1016/j.jash.2013.07.007

8. De la Sierra A, Segura J, Banegas JR, et al. Clinical features of 8295 patients with resistant hypertension classified on the basis of ambulatory blood pressure monitoring. Hypertension 2011;57:898-902.

http://dx.doi.org/10.1161/HYPERTENSIONAHA.110.168948

9. De Nicola L, Gabbai FB, Agarwal R, et al. Prevalence and prognostic role of resistant hypertension in chronic kidney disease patients. J Am Coll Cardiol 2013;61:2461-2467. http://dx.doi.org/10.1016/j.jacc.2012.12.061

10. Pierdomenico SD, Lapenna D, Bucci A, et al. Cardiovascular outcome in treated hypertensive patients with responder, masked, false resistant, and true resistant hypertension. Am J Hypertens 2005;18:1422-1428. http://dx.doi.org/10.1016/j.amjhyper.2005.05.014

11. MoserM, Setaro JF. Clinical practice. Resistant or difficult-tocontrol hypertension. N Engl J Med 2006;355:385-92. http://dx.doi.org/10.1056/NEJMcp041698

12. Pimenta E, Calhoun DA, Oparil S. Mechanisms and treatment of resistant hypertension. Arq Bras Cardiol 2007;88:683-92. http://dx.doi.org/10.1590/S0066-782X2007000600009

13. Makris A, Seferou M, Papadopoulos DP. Resistant hypertension workup and approach to treatment. Int J Hypertens 2011:598694. http://dx.doi.org/10.4061/2011/598694

14. Pimenta E, Calhoun DA. Resistant hypertension: incidence, prevalence, and prognosis. Circulation 2012;125:1594-6. http://dx.doi.org/10.1161/CIRCULATIONAHA.112.097345

15. Daugherty SL, Powers JD, Magid DJ, et al. Incidence and prognosis of resistant hypertension in hypertensive patients. Circulation 2012;125(13):1635-42. http://dx.doi.org/10.1161/CIRCULATIONAHA.111.068064

16. Khan TV, Khan SS, Akhondi A, Khan TW. White coat hypertension: relevance to clinical and emergency medical services personnel. Med Gen Med 2007;9:52.

17. Oliveira-Filho AD, Barreto-Filho JA, Neves SJ, et al. Association between the 8-item Morisky Medication Adherence Scale (MMAS-8) and blood pressure control. Arq Bras Cardiol 2012;99:649-658. http://dx.doi.org/10.1590/S0066-782X2012005000053

18. Morisky DE, Ang A, Krousel-Wood M,et al. Predictive validity of a medication adherence measure in an outpatient setting. J Clin Hypertens (Greenwich) 2008;10:348-54. http://dx.doi.org/10.1111/j.1751-7176.2008.07572.x

19. Maurer $\mathrm{H}$, Pfleger $\mathrm{K}$. Identification and differentiation of beta-blockers and their metabolites in urine by computerized gas chromatographymass spectrometry. J Chromatogr 1986;382:147-165. http://dx.doi.org/10.1016/S0378-4347(00)83513-6

20. Maurer HH. Systematic toxicological analysis procedures for acidic drugs and/or metabolites relevant to clinical and forensic toxicology and/or doping control. J Chromatogr B Biomed Sci Appl 1999;733:3-25. http://dx.doi.org/10.1016/S0378-4347(99)00266-2

21. Maurer $\mathrm{HH}$. Perspectives of liquid chromatography coupled to lowand high-resolution mass spectrometry for screening, identification, and quantification of drugs in clinical and forensic toxicology. Ther Drug Monit 2010;32:324-327. http://dx.doi.org/10.1097/FTD.0b013e3181dca295

22. Ojanpera" L, Pelander A, Laks S,et al. Application of accurate mass measurement to urine drug screening. J Anal Toxicol 2005;29:34-40. http://dx.doi.org/10.1093/jat/29.1.34

23. Maurer $\mathrm{HH}$, Tenberken $\mathrm{O}$, Kratzsch $\mathrm{C}$, et al. Screening for library-assisted identification and fully validated quantification of 22 beta-blockers in blood plasma by liquid chromatographymass spectrometry with atmospheric pressure chemical ionization. J Chromatogr A 2004;1058:169-181. http://dx.doi.org/10.1016/S0021-9673(04)01308-1

24. Kristoffersen L, Øiestad EL, Opdal MS,et al. Simultaneous determination of 6 beta-blockers, 3 calcium-channel antagonists, 4 angiotensin-II antagonists and 1 antiarrhythmic drug in postmortem whole blood by automated solid phase extraction and liquid chromatography mass spectrometry. Method development and robustness testing by experimental design. J Chromatogr B Analyt Technol Biomed Life Sci 2007;850:147-160.

http://dx.doi.org/10.1016/j.jchromb.2006.11.030

25. Zyoud SH, Al-Jabi SW, Sweileh WM, et al. Health-related quality of life associated with treatment adherence in patients with hypertension: a cross-sectional study. Int J Cardiol 2013;168:2981-3. http://dx.doi.org/10.1016/j.ijcard.2013.04.105

26. Parikh A, Lipsitz SR, Natarajan S. Association between a DASH-like diet and mortality in adults with hypertension: findings from a populationbased follow-up study. Am J Hypertens 2009;22:409-416. http://dx.doi.org/10.1038/ajh.2009.10

27. Rossi A, Dikareva A, Bacon SL, at al. The impact of physical activity on mortality in patients with high blood pressure: a systematic review. J Hypertens 2012;30:1277-1288. http://dx.doi.org/10.1097/HJH.0b013e3283544669

28. He FJ, Li J, Macgregor GA. Effect of longer term modest salt reduction on blood pressure. BMJ 2013;346:f1325. http://dx.doi.org/10.1136/bmj.f1325

29. Pimenta E, Gaddam KK, Oparil S, et al. Effects of dietary sodium reduction on blood pressure in subjects with resistant hypertension. Hypertension 2009;54:475-481. http://dx.doi.org/10.1161/HYPERTENSIONAHA.109.131235

30. Centers for Disease Control and Prevention (CDC). Usual sodium intakes compared with current dietary guidelinesUnited States, 2005-2008. MMWR Morb Mortal Wkly Rep 2011;60:1413-1417.

31. Dimeo F, Pagonas N, Seibert F, at al. Aerobic exercise reduces blood pressure in resistant hypertension. Hypertension 2012;60:653-658.

http://dx.doi.org/10.1161/HYPERTENSIONAHA.112.197780

32. Kokkinos PF, Narayan P, Colleran JA, et al. Effects of regular exercise on blood pressure and left ventricular hypertrophy in African-American men with severe hypertension. New England Journal of Medicine 1995;333:1462-1467. http://dx.doi.org/10.1056/NEJM199511303332204

33. Whelton PK, Appel LJ, Espeland MA, et al. Sodium Reduction and Weight Loss in the Treatment of Hypertension in Older Persons: A Randomized Controlled Trial of Nonpharmacologic Interventions in the Elderly (TONE). JAMA: the journal of the American Medical Association 1998;279:839-846. http://dx.doi.org/10.1001/jama.279.11.839

34. Conlin PR, Erlinger TP, Bohannon A, et al. The DASH diet enhances the blood pressure response to losartan in hypertensive patients. American Journal of Hypertension 2003;16:337342.

http://dx.doi.org/10.1016/S0895-7061(03)00056-6

35. Burke V, Beilin LJ, Cutt HE, et al. Effects of a lifestyle programme on ambulatory blood pressure and drug dosage in treated hypertensive patients: a randomized controlled trial. 
Journal of Hypertension 2005;23:1241-1249. http://dx.doi.org/10.1097/01.hjh.0000170388.61579.4f

36. Bray GA, Vollmer WM, Sacks FM et al. A further subgroup analysis of the effects of the DASH diet and three dietary sodium levels on blood pressure: results of the DASH-Sodium Trial. Am J Cardiol 2004;94:222-227. http://dx.doi.org/10.1016/j.amjcard.2004.03.070

37. Pimenta E, Gaddam KK, Pratt-Ubunama MN et al. Relation of dietary salt and aldosterone to urinary protein excretion in subjects with resistant hypertension. Hypertension 2008;51:339-344.

http://dx.doi.org/10.1161/HYPERTENSIONAHA.107.100701

38. Vogt L, Waanders F, Boomsma F et al. Effects of dietary sodium and hydrochlorothiazide on the antiproteinuric efficacy of losartan. J Am Soc Nephrol 2008;19:999-1007. http://dx.doi.org/10.1681/ASN.2007060693

39. Sarafidis PA, Bakris GL. Resistant hypertension: an overview of evaluation and treatment. J Am Coll Cardiol 2008;52:17491757. http://dx.doi.org/10.1016/j.jacc.2008.08.036

40. Messerli FH, Makani H, Benjo A et al. Antihypertensive efficacy of hydrochlorothiazide as evaluated by ambulatory blood pressure monitoring: ameta-analysis of randomized trials. J Am Coll Cardiol 2011;57:590-600. http://dx.doi.org/10.1016/j.jacc.2010.07.053

41. Carter BL, Ernst ME, Cohen JD. Hydrochlorothiazide versus chlorthalidone: evidence supporting their interchangeability. Hypertension 43:4-9. http://dx.doi.org/10.1161/01.HYP.0000103632.19915.0E

42. Ernst ME, Carter BL, Goerdt CJ et al. Comparative antihypertensive effects of hydrochlorothiazide and chlorthalidone on ambulatory and office blood pressure. Hypertension 2006;47:352-358. http://dx.doi.org/10.1161/01.HYP.0000203309.07140.d3

43. Moser M, Cushman W, Handler J. Resistant or difficult-totreat hypertension. J Clin Hypertens (Greenwich) 2006;8:434440. http://dx.doi.org/10.1111/j.1524-6175.2006.05328.x

44. Ernst ME, Gordon JA. Diuretic therapy: key aspects in hypertension and renal disease. J Nephrol 2010;23:487-493.

45. Bomback AS, Klemmer PJ. The incidence and implications of aldosterone breakthrough. Nat Clin Pract Nephrol 2007;3:486-492.

http://dx.doi.org/10.1038/ncpneph0575

46. Duprez DA. Aldosterone and the vasculature: mechanisms mediating resistant hypertension. J Clin Hypertens (Greenwich) 2007;9:13-18. http://dx.doi.org/10.1111/j.1524-6175.2007.06367.x

47. Doulton TW, He FJ, MacGregor GA. Systematic review of combined angiotensin-converting enzyme inhibition and angiotensin receptor blockade in hypertension. Hypertension 2005;45:880-886.

http://dx.doi.org/10.1161/01.HYP.0000161880.59963.da

48. Berl T. Maximizing inhibition of the renin-angiotensin system with high doses of converting enzyme inhibitors or angiotensin receptor blockers. Nephrol Dial Transplant 2008;23:2443-2447. http://dx.doi.org/10.1093/ndt/gfn239

49. Gaddam KK, Nishizaka MK, Pratt-Ubunama MN et al. Characterization of resistant hypertension: association between resistant hypertension, aldosterone, and persistent intravascular volume expansion. Arch Intern Med 2008;168:1159-1164. http://dx.doi.org/10.1001/archinte.168.11.1159

50. Chapman N, Dobson J, Wilson S et al. Effect of spironolactone on blood pressure in subjects with resistant hypertension.
Hypertension 2007;49:839-845.

http://dx.doi.org/10.1161/01.HYP.0000259805.18468.8c

51. Vaclavik J, Sedlak R, PlachyM et al. Addition of spironolactone in patients with resistant arterial hypertension (ASPIRANT): a randomized, doubleblind, placebo-controlled trial. Hypertension 2011;57:1069-1075. http://dx.doi.org/10.1161/HYPERTENSIONAHA.111.169961

52. Pisoni R, Acelajado MC, Cartmill FR et al. Long-term effects of aldosterone blockade in resistant hypertension associated with chronic kidney disease. J Hum Hypertens 2012;26:502-506. http://dx.doi.org/10.1038/jhh.2011.60

53. Khosla N, Kalaitzidis R, Bakris GL. Predictors of hyperkalemia risk following hypertension control with aldosterone blockade. Am J Nephrol 2009;30:418-424. http://dx.doi.org/10.1159/000237742

54. Pogue V, Rahman M, Lipkowitz M et al. Disparate estimates of hypertension control from ambulatory and clinic blood pressure measurements in hypertensive kidney disease. Hypertension 2009;53:20-27. http://dx.doi.org/10.1161/HYPERTENSIONAHA.108.115154

55. Ohkubo T, Hozawa A, Yamaguchi J et al. Prognostic significance of the nocturnal decline in blood pressure in individuals with and without high 24-h blood pressure: the Ohasama study. J Hypertens 2002;20:2183-2189. http://dx.doi.org/10.1097/00004872-200211000-00017

56. Muxfeldt ES, Cardoso CR, Salles GF. Prognostic value of nocturnal blood pressure reduction in resistant hypertension. Arch Intern Med 2009;169:874-880. http://dx.doi.org/10.1001/archinternmed.2009.68

57. Bankir L, Bochud M, Maillard $M$ et al. Nighttime blood pressure and nocturnal dipping are associated with daytime urinary sodium excretion in African subjects. Hypertension 2008;51:891-898.

http://dx.doi.org/10.1161/HYPERTENSIONAHA.107.105510

58. Hermida RC, Ayala DE, Fernandez JR et al. Chronotherapy improves blood pressure control and reverts the nondipper pattern in patients with resistant hypertension. Hypertension 2012;51:69-76.

http://dx.doi.org/10.1161/HYPERTENSIONAHA.107.096933

59. Almirall J, Comas L, Martinez-Ocana JC et al. Effects of chronotherapy on blood pressure control in non-dipper patients with refractory hypertension. Nephrol Dial Transplant 2012;27:1855-1859.

http://dx.doi.org/10.1093/ndt/gfr557

60. Kontak AC,Wang Z, Arbique D, et al. Reversible sympathetic overactivity in hypertensive patients with primary aldosteronism. J Clin Endocrinol Metab 2010;95:4756-4761. http://dx.doi.org/10.1210/jc.2010-0823

61. Bisognano JD, Bakris G, Nadim MK, et al. Baroreflex activation therapy lowers blood pressure in patients with resistant hypertension: results from the double-blind, randomized, placebo-controlled rheos pivotal trial. J Am Coll Cardiol 2011;58:765-773. http://dx.doi.org/10.1016/j.jacc.2011.06.008

62. Esler MD, Krum H, Sobotka PA, at al. SYMPLICITY HTN-2 Investigators. Renal sympathetic denervation in patients with treatment-resistant hypertension (the SYMPLICITY HTN-2 Trial): a randomised controlled trial. Lancet 2010;376:19031909. http://dx.doi.org/10.1016/S0140-6736(10)62039-9

63- Bhatt DL, Kandzari DE, O'NeillWW, et al. SYMPLICITY HTN-3 Investigators. A controlled trial of renal denervation for resistant hypertension. N Engl J Med 2014;370:1393-1401. http://dx.doi.org/10.1056/NEJMoa1402670 